\title{
O AUTOFÁGICO DIREITO PENAL DO INIMIGO: POR UMA RESISTÊNCIA GARANTISTA
}

\author{
Matheus Almeida Caetano * \\ Sumário: 1. Intróito - 2. Prolegômenos do Direito Penal do Inimigo \\ (Feindstrafrecht) de Jakobs desde 1985 - 3. Idéias centrais do Direito \\ Penal do Inimigo por Jakobs - 4. O Direito Penal do Inimigo: a negação \\ do Direito Penal e retrocessos ao Garantismo - 4.1 Lombroso-Mezger- \\ Jakobs, uma análise da proximidade destes discursos com um direito \\ penal de autor (Täterstrafrecht): primeiro retrocesso - $4.2 \mathrm{O}$ Direito \\ como mera legitimação interna ou jurídica: segundo retrocesso - $4.3 \mathrm{~A}$ \\ legitimação da violência estatal para manutenção do Estado de Direi- \\ to? terceiro retrocesso - 4.4 A supressão de garantias e ofensa aos \\ direitos fundamentais: quarto retrocesso - 4.5 A "neutralidade" do \\ Direito Penal do Inimigo e a sua falácia naturalista: quinto retrocesso - \\ 5. O 11 de Setembro...War against terror...USA Patriot Act... - 6. À gui- \\ sa de conclusão - 7. Referências.
}

- RESUMO: Desde 1985, o tema vem causando impacto sobre o pensamento penal contemporâneo, gerando uma infinidade de trabalhos acadêmicos e obras. O presente artigo objetiva fazer uma breve exposição das principais características que compõem o que Günther Jakobs denomina de "Direito Penal do Inimigo" (Feindstrafrecht). Posteriormente, algumas críticas são colocadas de forna a demonstrar tanto a ausência de qualquer novidade do tema - já que sempre existiu um inimigo para o sistema penal quanto a confusão entre direito e guerra (acusado e combatente), o que leva a própria negação do Direito Penal. Conclui-se, ao final, pelo abandono dessa construção teórica, responsável por retrocessos significativos de índole garantista.

- PAlAVRAS-CHAVE: Direito Penal do Inimigo - Garantismo - Estado de Direito - Direitos Fundamentais.

- $\quad$ ABSTRACT: Since 1985, the theme has been causing impact in contemporary criminal thought, motivating an infinity of academic papers and books. This paper aims to do a concise exposition about the main features that constitute what Guther Jakobs designates "Criminal Law for the Enemy" (Feindstrafrecht). Then, some comments are made to demonstrate both the absence of any news in the theme - since there was always an enemy for the criminal system - and a confusion between law and war (accused and warrior), which leads to the negation of Criminal Law. It is concluded by the end, for the abandonment of this theoretical construction, responsible for significant setbacks of garantism character.

- KEY WORDS: Criminal Law for the Enemy - Garantism - Rule of Law - Fundamental Rights.

\section{INTRÓITO}

O presente artigo intenta expor, primeiramente, o Direito Penal do Inimigo (Feindstrafrecht/ DPI) com algumas de suas características, tais quais foram levantadas por Günther JAKOBS. Adentrando-se na compreensão de alguns conceitos utilizados por este autor, buscar-se-á defraudar as expectativas criadas em torno desta construção dogmática e apontar suas conseqüências lógicas: (i) a otimização

\footnotetext{
Mestrando em Direito pela Universidade Federal de Santa Catarina (UFSC), da área de concentração "Direito, Estado e Sociedade", bolsista CAPES-Brasil. Especialista em Ciências Penais pela Universidade do Sul de Santa Catarina (UNISUL). Advogado. Email para contato: matheusalmeyda@hotmail.com.
} 
da "cifra da injustiça"1 pelo Estado com retrocessos para o Garantismo e (ii) o risco de dissolução do próprio Direito Penal e do Estado Democrático de Direito pelas graves violações de direitos fundamentais legitimadas por ela.

A escolha do tema justifica-se em razão da grande difusão do mesmo nos debates acadêmicos ${ }^{2}$ e legislativos dos Estados, e principalmente por ser defendido pelo penalista alemão como um instrumento de preservação da estrutura do Estado Democrático de Direito. Por fim, como se propõe deixar claro ao longo deste trabalho, não só a pesada carga semântica do termo "inimigo" é responsável pelas críticas em torno deste tão comentado tema, embora JAKOBS advirta que "[...] debe acotarse con carácter previo que la denominación 'Derecho penal del enemigo' no en todo caso pretende ser peyorativa" ${ }^{3}$. Assim o autor parece dar margem àlguma possibilidade de sê-lo, o que é preocupante, no mínimo, por legitimar um direito penal seletivo e altamente cruento, marcado por um triste cotidiano legislativo, policial e jurisdicional de indiferença e de pisoteamento das garantias jurídico-penais e dos direitos fundamentais.

\section{PROLEGÔMENOS DO DIREITO PENAL DO INIMIGO (FEINDSTRAFRECHT) DE JAKOBS DESDE 1985}

A frase proferida por JAKOBS durante as Jornadas de penalistas alemães em Frankfurt no ano de 1985 - a qual integra o seu trabaho "Criminalizações no estádio prévio à lesão a bem jurídico"4 - de que "[...] el Derecho penal de enemigos optimiza la protección de bienes jurídicos, el Derecho penal de ciudadanos optimiza las esferas de libertad"5, iniciou um dos temas mais polêmicos da atualidade na Dogmática Jurídico-Penal e na Política Criminal. Deste trecho já se nota a proposta de uma bifurcação do Direito Penal em Direito Penal do Inimigo (Feindstrafrecht) e

\footnotetext{
${ }^{1}$ FERRAJOLI, Luigi. Direito e Razão: teoria do garantismo penal. Tradução de Ana Paula Zomer, Fauzi Hassan Choukr, Juarez Tavares et al. São Paulo: RT, 2002, p.168: “[...]adiciona-se uma cifra, não menos obscura, mas ainda mais inquietante e intolerável, formada pelo número de nocentes processados,e às vezes, punidos".

${ }^{2}$ FERRAJOLI, Luigi. El "Derecho Penal del Enemigo" y la disolución del Derecho Penal. CARBONELL, Miguel (Ed.). Democracia y garantismo. Madrid: Editorial Trotta, 2008, p.234: "[...] que sobre ella se realicen congresos (dos solo en Italia en este mês); y en torno a la misma esté creciendo, como inevitablemente sucede en la comunidad de los juristas, uma rica literatura".

${ }^{3}$ JAKOBS, Günther. Derecho Penal del ciudadano y Derecho Penal del enemigo. In: ; POLAINO NAVARRETE, Miguel.

El Derecho Penal ante las sociedades modernas: dos estúdios de dogmática penal y política criminal. Lima: Grijley, 2006, p.23.

${ }^{4}$ JAKOBS, Günther. Criminalización em el estadio previo a la lesión de un bien juridico. Estudios de Derecho Penal. Traducción de Enrique Peñaranda Ramos, Carlos J. Suárez González y Manuel Cancio Meliá. Madrid: Civitas, 1997.

${ }^{5}$ JAKOBS, Günther. Criminalización em el estadio previo a la lesión de un bien juridico. Estudios de Derecho Penal. Traducción de Enrique Peñaranda Ramos, Carlos J. Suárez González y Manuel Cancio Meliá. Madrid: Civitas, 1997, p.298.

se sabe o que é".
} 
Direito Penal do Cidadão (Bürgerstrafrecht). Também cabe uma primeira advertência de que há muita celeuma em torno desse conceito na literatura penal, o que acaba por gerar uma infinidade de especulações e mal entendidos. O DPI não é de fácil compreensão, e não está consagrado na Dogmática Jurídico-Penal, ao contrário, vem sendo discutido desde 1985 até os dias de hoje. Presente, então, a primeira dificuldade do objeto de estudo: sua obscuridade 6 .

Indispensável ter em conta, no mínimo, um breve conhecimento do pensamento de JAKOBS - responsável que é pela introdução do conceito no debate científico-penal ${ }^{7}$ - e de suas premissas metodológicas, para que o estudo ganhe em riqueza e que as críticas sejam pertinentes e sustentadas. Toda construção deste penalista alemão incorpora elementos estruturais da Filosofia de HEGEL, KANT, HOBBES e de outros pensadores, além da Sociologia de Niklas LUHMANN, o que acaba por gerar uma construção própria de uma Teoria do Estado. Desta advêm vários aspectos que induzem o Direito Penal, trabalhados pelo autor com um particular ponto de vista, como sua teoria da pena e os delitos de infração de dever (Pflichtdelikte), dentre outros temas correlatos que não podem ser aprofundados neste artigo. Além disso, existem três formas de abordagem do Feindstrafrecht $t^{8}$ (i) uma primeira como conceito afirmativo-legitimador, havendo aqui uma dogmática que reflete as normas existentes no ordenamento jurídico de um Estado; (ii) uma segunda como conceito meramente descritivo, no qual há uma mera constatação

\footnotetext{
${ }^{6}$ GRECO, Luís. Sobre o chamado Direito Penal do Inimigo. Revista da Faculdade de Direito de Campos, Rio de Janeiro, Ano VI, n. ${ }^{0}$ 7, dez.2005, p.213: "Parece-me que o tal direito penal do inimigo não é algo tão claro e unívoco quanto geralmente se supõe, sendo necessário realizar algumas precisões para que o debate possa tornar-se de fato fecundo. Dificilmente pode-se discutir a respeito de algo que mal.

${ }^{7}$ MUÑOZ CONDE, Francisco. De nuevo sobre el "Derecho penal del enemigo". Buenos Aires: Hammurabi, 2005, p.19: “[...] de um 'Derecho penal del enemigo', con este o con otro nombre, no es un invento del Sr. JAKOBS, sino una realidad evidente y cada vez más preocupante [...]". No mesmo sentido assevera Luis Gracia-Martin, in GRACIA MARTIN, Luis. Prolegômenos para a luta pela modernização e expansão do direito penal e para a crítica do discurso de resistência. Tradução de Érika Mendes de Carvalho. Porto Alegre: Sérgio Antonio Fabris Editor, 2005, p.86: "O 'Direito penal do inimigo' foi introduzido no discurso teórico atual por Jakobs como um conceito doutrinário que se opõe a um Direito penal do cidadão".

${ }^{8}$ Tal delimitação facilita a compreensão do tema proposto e foi bem enunciada pelo penalista brasileiro Luís GRECO. Mais detalhes em: GRECO, Luís. Sobre o chamado Direito Penal do Inimigo. Revista da Faculdade de Direito de Campos, Rio de Janeiro, Ano VI, n. ${ }^{\circ}$ 7, dez.2005. Também é de se destacar a classificação mais direta e simplificada de Luigi FERRAJOLI, utilizando-se dois sentidos para o direito penal do inimigo nos seguintes termos: "[...] a) uno de tipo empírico-descriptivo; descriptivo, entiéndase bien, de una perversión del derecho penal, es decir, de prácticas punitivas y represivas - pienso em las jaulas de Guantánamo o en las torturas de Abu Ghraib - que se cobren con el manto del derecho penal y son, por el contrario, su negación; y b) outro significado, podría decirse, de tipo eórico, merced al qual 'el derecho penal del enemigo'resulta presentado o recomendado como un nuevo 'paradigma', un nuevo 'modelo', como tal normativo, de derecho pena" (FERRAJOLI, Luigi. El "Derecho Penal del Enemigo" y la disolución del Derecho Penal. CARBONELL, Miguel (Ed.). Democracia y garantismo. Madrid: Editorial Trotta, 2008, p.236).
} 
da realidade legislativa daqueles Estados que incorporam normas de um DPI; (iii) e por último, uma concepção denunciadora-crítica, a primeira a surgir com JAKOBS em 1985, na qual algumas críticas foram traçadas aos institutos jurídicos que despontavam no ordenamento jurídico alemão como a antecipação das barreiras punitivas e a incriminação de atos preparatórios. Desta forma, necessário é entender qual das abordagens será criticada, sob pena de se cometerem erros lógicos, confundindo os diversos sentidos do DPI supramencionados.

O tema guarda uma forte ligação com a categoria do bem jurídico-penal, pois JAKOBS considerou o infrator da norma como inimigo do bem jurídico ${ }^{9}$. O ponto de partida do bem jurídico, entendido como função do Direito Penal, é o germe do Direito Penal do Inimigo, para este autor alemão. Neste primeiro momento, JAKOBS adotou uma postura crítica (abordagem denunciadora-crítica-iii), salientando que "[...] el Derecho penal de enemigos sólo se puede legitimar como Derecho penal de emergencia que rige excepcionalmente" ${ }^{10}$. Tratava-se naquele momento, de um juízo descritivo do DPI, em tom crítico, denunciando as antecipações das barreiras punitivas de proteção aos bens jurídicos erguidas pelo legislador alemão, as punições tanto dos atos preparatórios quanto das tentativas, independentemente da idoneidade das mesmas, baseando-se no princípio jurídico-penal cogitationis poenam nemo patitur.

A partir de 1997 - quando JAKOBS publica a obra intitulada "Norm, Person und Gesellschaft"11 - seguem-se algumas manifestações do autor sobre o tema, destacando-se: o trabalho sobre o estado atual da teoria da pena (1998); a palestra proferida no ano de 1999 na Espanha (e de forma resumida em Berlim, no fim do mesmo ano) sobre "la Ciencia jurídico-penal ante los retos de la actualidad"12; a manifestação em 2001 sobre os atentados de 11 de setembro contra os Estados Unidos da América (texto manuscrito inédito até o presente momento); e um artigo sobre "Personalidad y exclusión en Derecho Penal"13. Nesses trabalhos, o jurista alemão já dava ares de uma legitimação do Feindstrafrecht (abordagem afirmativa-

\footnotetext{
${ }_{9}$ JAKOBS, Günther. Criminalización em el estadio previo a la lesión de un bien juridico. Estudios de Derecho Penal. Traducción de Enrique Peñaranda Ramos, Carlos J. Suárez González y Manuel Cancio Meliá. Madrid: Civitas, 1997, p.295: “[...] es sólo fuente de peligro o, con otras palabras, enemigo del bien jurídico".

${ }^{10}$ JAKOBS, Günther. Criminalización em el estadio previo a la lesión de un bien juridico. Estudios de Derecho Penal. Traducción de Enrique Peñaranda Ramos, Carlos J. Suárez González y Manuel Cancio Meliá. Madrid: Civitas, 1997, p.322.

${ }^{11}$ Trata-se de obra inédita nas línguas espanhola e portuguesa, já que a obra "Sociedade, Norma e Pessoa", publicada pela Editora Manole no Brasil, tradução de Maurício Antonio Ribeiro Lopes em 2003, não equivale à referida obra. Para mais informações consultar rodapé de número $21 \mathrm{em:} \mathrm{POLAINO}$ ORTS, Miguel. Derecho penal del enemigo: desmitificación de un concepto. Lima: Grijley, 2006, p.35. ${ }^{12}$ POLAINO ORTS, Miguel. Derecho penal del enemigo: desmitificación de un concepto. Lima: Grijley, 2006, p.35.

${ }^{13}$ JAKOBS, Günther. Personalidad y exclusión en Derecho Penal. Traducción de Teresa Manso Porto. In: MONTEALEGRE LYNETT, Eduardo (Cood.). El Funcionalismo en Derecho Penal. Libro Homenaje al Profesor Günther Jakobs. Tomo II. Bogotá: Universidad Externado de Colombia, 2003, pp.73 e ss.
} 
legitimadora-i). Por fim, em 2008 publicou "Derecho penal del enemigo? Un estudio acerca de los presupuestos de la juridicidad", tradução do alemão para o espanhol feita por Manuel CANCIO MELIÁ. Este último trabalho foi objeto de várias conferências realizadas por JAKOBS ${ }^{14}$.

\section{IDÉIAS CENTRAIS DO DIREITO PENAL DO INIMIGO POR JAKOBS}

Feito um breve histórico do desenvolvimento do tema, chegado o momento de apontar algumas de suas características e de explicar suas idéias centrais. Salienta-se que o inimigo, é para JAKOBS “[...] um indivíduo que, mediante seu comportamento, sua ocupação profissional ou, principalmente, mediante sua vinculação a uma organização, abandonou o Direito de modo supostamente duradouro e não somente de maneira incidental"15. Não deixa de ser uma constatação fática das legislações penais atuais, estando presente, inclusive, na legislação penal brasileira ${ }^{16}$, é utilizado com freqüência na tipificação e no tratamento de delitos relacionados ao terrorismo, à criminalidade organizada, ao tráfico de drogas e aos crimes sexuais e econômicos, conforme pensamento de JAKOBS ${ }^{17}$. Em síntese, podem-se elencar as suas principais peculiaridades: (i) o inimigo não está sujeito a pena e sim a medidas de segurança, em razão de sua periculosidade social (e não

\footnotetext{
${ }^{14}$ JAKOBS, Günther. Derecho penal del enemigo? Un estudio acerca de los presupuestos de la juridicidad. Traddución de Manuel Cancio Meliá. Panóptica, Vitória, ano 2, n. 11, nov. - fev. 2008, p.197, única nota de rodapé:"Título alemán: 'Feindstrafrecht? Eine Untersuchung zu den Bedingungen von Rechtlichkeit'(manuscrito). Conferencia presentada, con algunas diferencias en la formulación, (1) en la Jornada 'Feindstrafrecht. Vereinbar mit dem Rechtsstaat' de la Katholische Akademie Trier (noviembre de 2005), (2) en el 'Convegno: Delitto Politico e Diritto Penal del Nemico' de la Universitá degli Studi di Trento, Sardagna, Trento (marzo de 2006) y (3) en el grupo de trabajo 'Feindstrafrecht. Ein Gespenst geht um im Rechtsstaat' del $30^{\circ}$ Strafverteidigertag, Frankfurt am Main (marzo de 2006)". ${ }^{15}$ SILVA SÁNCHEZ, Jesús-Maria. A expansão do direito penal: aspectos da política criminal nas sociedades pós-industriais. Tradução de Luiz Otavio de Oliveira Rocha. São Paulo: RT, 2002, p.149. ${ }^{16}$ GRECO, Rogério. Direito Penal do Equilíbrio: uma visão minimalista do Direito Penal. $2^{\mathrm{a}} \mathrm{ed}$. Rio de Janeiro: Impetus, 2006, p.23: "O Direito Penal do Inimigo, conforme salienta Jakobs, já existe em nossas legislações, gostemos ou não disso, a exemplo do que ocorre no Brasil com a lei que dispõe sobre a utilização de meios operacionais para a prevenção de ações praticadas por organizações criminosas (Lei n. ${ }^{\circ}$ 9.034, de 3 de maio de 1995)".

${ }^{17}$ JAKOBS, Günther. Derecho Penal del Ciudadano y Derecho Penal del Enemigo. In: JAKOBS, Günther; CANCIO MELIÁ, Manuel. Derecho Penal del Enemigo. Madrid: Civitas, 2003, p.38/40: "Así, por ejemplo, el legislador (por permanecer primero en el ámbito del Derecho material) está pasando a una legislación - denominada abiertamente de este modo - de lucha, por ejemplo, en el ánibito de la criminalidad económica, del terrorismo, de la criminalidad organizada, en el caso de <delitos sexuales y otras infracciones penales peligrosas $>$ así como, en general, respecto de los <crímenes $>$, pretendiéndose combatir em cada uno de estos casos a individuos que en su actitud (por ejemplo, en el caso de los delitos sexuales), en su vida económica (así, por ejemplo, en el caso de la criminalidad económica, de la criminalidad relacionada con las drogas tóxicas y de otras formas de criminalidad organizada) o mediante su incorporación a una organización (em el caso del terrorismo, en la criminalidad organizada, incluso ya en la conspiración para delinquir, ( $\$ 30 \mathrm{StGB}$ ) se han apartado probablemente de manera duradera, al menos de modo decidido, del Derecho, es decir, que no prestan la garantía cognitiva mínima que es necesaria para el tratamiento como persona".
} 
culpabilidade) ${ }^{18}$; (ii) o inimigo é visto como uma fonte de perigo que deve ser isolada, não fazendo jus ao tratamento de pessoa em Direito ${ }^{19}$; (iii) o inimigo é tratado como coisa, mero objeto da tutela penal ${ }^{20}$; (iv) constitui um direito penal do autor (Täterstrafrecht $)^{21}$ e não do fato; (v) permite a supressão de garantias materiais e processuais penais.

Decorrente da cisão propugnada por JAKOBS, enquanto o cidadão comete delitos, não colocando em xeque o ordenamento jurídico, e, por isso, sendo apenado como conseqüência da sua condição de pessoa, o inimigo ao colocar em perigo o próprio Estado com as suas estruturas (considerada uma verdadeira ameaça às bases do Sistema Social) será objeto de medida de segurança, conseqüência de sua condição de não-pessoa, indivíduo perigoso. Ora, no campo do Bürgerstrafrecht, a concepção de pena recebe influência direta do pensamento hegeliano, colocada numa estrutura dialética muito bem ressaltada por Paulo de Souza QUEIROZ, já que: "Vale dizer: o delito é uma violência contra o direito, a pena uma violência que anula aquela primeira violência; é, assim, a negação da negação do direito representada pelo delito (segundo a regra, a negação da negação é a sua afirmação)" 22 . A resposta adequada (a pena) à infração da norma (delito) visa ao restabelecimento da mesma (norma), conservando-se aqui, a estrutura comum dos delitos, auferindo-se a responsabilidade penal do autor através de sua culpabilidade: "Delito y pena han de concebirse como mensaje y respuesta respecto de la vigencia

${ }^{18}$ SILVA SÁNCHEZ, Jesús-Maria. A expansão do direito penal: aspectos da política criminal nas sociedades pós-industriais. Tradução de Luiz Otavio de Oliveira Rocha. São Paulo: RT, 2002, p. 149150: "[...] se manifestaria uma dimensão fática de periculosidade, a qual teria que ser enfrentada de um modo prontamente eficaz";

AMARAL, Cláudio do Prado. Bases Teóricas da Ciência Penal Contemporânea: dogmática, missão do direito penal e política criminal na sociedade de risco. São Paulo: IBCCRIM, 2007, p.127: “[...] a) o inimigo não pode ser punido com pena, mas, sim, com medida de segurança; b) deve ser punido de acordo com sua periculosidade, e não conforme a sua culpabilidade;".

${ }^{19}$ JAKOBS ultiliza de vários conceitos de pessoa para justificar sua teorização do inimigo, seja de Kelsen como "[...] um complexo de deveres jurídicos e direitos sujectivos cuja unidade é figurativamente expressa no conceito de pessoa. A pessoa é tão somente a personificação desta unidade", ou de Hegel defendendo "O imperativo do direito é portanto: sê uma pessoa e respeita os outros como pessoas". Cfr. em: HEGEL, Georg Wilhem Friedrich. Princípios da Filosofia do Direito. Tradução de Orlando Vitorino. São Paulo: Martins Fontes, 1997, p.40; KELSEN, Hans. Teoria Pura do Direito. $4^{\mathrm{a} e d .}$ Tradução de João Baptista Machado. Coimbra: Armênio Amado Editor, 1976, pp.241-243;

${ }^{20}$ AMARAL, Cláudio do Prado. Bases Teóricas da Ciência Penal Contemporânea: dogmática, missão do direito penal e política criminal na sociedade de risco. São Paulo: IBCCRIM, 2007, p.127: "[...] e) o inimigo não é sujeito de direitos, mas, sim, objeto de coação;".

${ }^{21}$ MUÑOZ CONDE, Francisco. De nuevo sobre el 'Derecho Penal del enemigo'. Buenos Aires: Hammurabi, 2005, p.37: " La primera observación que se puede hacer a JAKOBS es que su 'Derecho penal del enemigo' recuerda mucho al 'Derecho penal de autor' que propugnaron los penalistas nazis, según el cual lo relevante no era el hecho delictivo cometido, sino la 'perversión', 'inclinación o tendência al delito' o 'peligrosidad criminal' que pudiera tener su autor".

${ }^{22}$ QUEIROZ, Paulo de Souza. Funções do Direito Penal: legitimação versus Deslegitimação do Sistema Penal. Belo Horizonte: Del Rey, 2001, p.21. 
de la norma"23. Neste Direito Penal do Cidadão o sujeito ativo conserva o status de pessoa, já que o núcleo do conceito social de pessoa para JAKOBS é "ter de representar um papel" ${ }^{24}$, ora, "[...] pessoa não atua conforme ao esquema individual de satisfação e insatisfação, mas conforme a um esquema de dever e espaço de liberdade" 25 . Desta forma, ao adentrar no conceito jurídico de pessoa para este autor alemão, resta claro que somente poderá sê-la "[...] quien es capaz jurídicamente. Por consiguiente, está excluido del ámbito de las personas aquél que no puede 'disfrutar' de ningún derecho ni soportar ningún deber; está parcialmente excluido quien no participa de determinados derechos y deberes" ${ }^{26}$.

Por outro lado, no Feindstrafrecht o tratamento do inimigo como uma "nãopessoa" reflete novamente a influência de HEGEL no pensamento do penalista alemão, pois quando o Direito atribui ao inimigo este pesado status em razão de ignorar o Direito, nada mais faz do que aplicar um conceito daquele filósofo alemão: "O imperativo do direito é portanto: sê uma pessoa e respeita os outros como pessoas" 27 . Ora, conforme os ensinamentos de JAKOBS: "(1) ser persona en Derecho es algo sinalagmático, el otro ha de 'participar', a menos que se dé la poco frecuente situación de que se lo tenga controlado como prisionero. Por lo tanto, la situación debe estar configurada como más o menos carente de riesgos" ${ }^{28}$. Disto decorre o critério utilizado para auferir a periculosidade do "indivíduo", entendida esta como: "[...] la probabilidad de que se produzca un resultado, en este caso la probabilidad de que se cometa en el futuro un delito por parte de una determinada persona"29.

A pecha de "não-pessoa" consiste no status utilizado pelo sistema jurídicopenal para lidar com aqueles indivíduos que escolheram viver fora da sociedade, ora, o tratamento destes inimigos " $[. .$.$] conduce a un derecho penal que no se dirige$ a personas sino a individuos los cuales en relación con un determinado comportamiento han de ser estimulados, en caso necesario desconectados y, ya en casos extremos, combatidos: derecho penal de enemigos" ${ }^{30}$. Ao não respeitarem e

\footnotetext{
${ }^{23}$ ALCÁCER GUIRAO, Rafael. ¿Lesión de bien jurídico o lesión de deber? Apuntes sobre el concepto material del delito. Lima: Grijley, 2004, p.83.

${ }^{24}$ JAKOBS, Günther. Sociedade, norma e pessoa: teoria de um direito penal funcional. Tradução de Maurício Antonio Ribeiro Lopes. Barueri: Manole, 2003, p.30.

${ }^{25}$ JAKOBS, Günther. Teoria da Pena e Suicídio e Homicídio a pedido. Tradução de Maurício Antonio Ribeiro Lopes. Barueri: Manole, 2003, p.9.

${ }^{26}$ JAKOBS, Günther. Personalidad y exclusión en derecho penal. In: MONTEALEGRE LYNETT, Eduardo (Coord.). El Funcionalismo en Derecho Penal. Libro Homenaje al professor Günther Jakobs. Bogotá: Universidad Externado de Colombia, 2003, p.73.

${ }^{27}$ HEGEL, Georg Wilhem Friedrich. Princípios da Filosofia do Direito. Tradução de Orlando Vitorino. São Paulo: Martins Fontes, 1997, p.40.

${ }^{28}$ JAKOBS, Günther. Derecho penal del enemigo? Un estudio acerca de los presupuestos de la juridicidad. Traddución de Manuel Cancio Meliá. Panóptica, Vitória, ano 2, n. 11, nov. - fev. 2008, p.200.

${ }^{29}$ MUÑOZ CONDE, Francisco. Introduccion al Derecho Penal. Barcelona: Bosch, 1975, p.39.

${ }^{30}$ JAKOBS, Günther. Personalidad y exclusión en derecho penal. In: MONTEALEGRE LYNETT, Eduardo (Coord.). El Funcionalismo en Derecho Penal. Libro Homenaje al professor Günther Jakobs. Bogotá: Universidad Externado de Colombia, 2003, p.86.
} 
nem acompanharem as normas sociais da sociedade na qual estão vivendo (ausência de fidelidade à norma jurídica), os inimigos carecem de uma garantia cognitiva suficiente para serem tratadas como pessoas, devendo ser corrigidos por medidas de segurança:

Por ejemplo, un autor que delinque una y otra vez de forma grave y no da muestra alguna de cambio en su comportamiento se convierte en objeto de internamiento preventivo ( $\$ 66 \mathrm{StGB}$ ), y éste significa, a diferencia de la pena, no que se le toma en serio como persona, sino que en lo que afecta a la administración de su libertad, a falta de una garantía cognitiva suficiente, ya no puede ser tratado como persona. En este sentido es, por tanto, excluido, o más exactamente, presentado como alguien que a través de su comportamiento se ha excluido a sí mismo. Dicho en sentido kantiano, la pena tiene lugar frente al homo noumenon; el internamiento preventivo, frente al homo phaenomenon. ${ }^{31}$

Traçadas as idéias centrais do DPI e algumas de suas características, no próximo item discorrer-se-á sobre alguns dos pontos de fricção da proposta de JAKOBS com um modelo de Direito Penal Garantista.

\section{O DIREITO PENAL DO INIMIGO: NEGAÇÃO DO DIREITO PENAL E RETROCESSOS AO GARANTISMO}

Após uma breve introdução ao direito penal do inimigo, nesta seção serão expostos os argumentos de deslegitimação desta construção teórica que nega a essência do Direito Penal. Inevitável é o autofagismo do Direito Penal provocado por essa teorização de JAKOBS, o que leva Luigi FERRAJOLI a tecer a seguinte colocação: "Creo que hay que reconocer con absoluta firmeza que hablamos de un oxímoron, de una contradicción en los términos, que representa, de hecho, la negación del derecho penal $[\ldots]^{\prime \prime 32}$.

O Garantismo merece algumas considerações preeliminares antes de se exporem seus aportes teóricos e as principais incompatibilidades com o Feindstrafrecht. Primeiramente, a Teoria Garantista é dotada de um amplo alcance, possuindo elementos bastantes para uma verdadeira teoria geral..$^{33}$ Além disso, este termo possui três significados diversos: (i) modelo normativo de direito; (ii)

\footnotetext{
${ }^{31}$ JAKOBS, Günther. Personalidad y exclusión en derecho penal. In: MONTEALEGRE LYNETT, Eduardo (Coord.). El Funcionalismo en Derecho Penal. Libro Homenaje al professor Günther Jakobs. Bogotá: Universidad Externado de Colombia, 2003, p.85.

${ }^{32}$ FERRAJOLI, Luigi. El "Derecho Penal del Enemigo" y la disolución del Derecho Penal. CARBONELL, Miguel (Ed.). Democracia y garantismo. Madrid: Editorial Trotta, 2008, p.235.

${ }^{33}$ FERRAJOLI, Luigi. Direito e Razão: teoria do garantismo penal. Tradução de Ana Paula Zomer, Fauzi Hassan Choukr, Juarez Tavares et al. São Paulo: RT, 2002, p.686: "Eles delineiam, precisamente, os elementos de uma teoria geral do garantismo: o caráter vinculado do poder público no Estado de direito; a divergência entre validade e vigor produzida pelos desníveis das normas e um certo grau irredutível de ilegitimidade jurídica das atividades normativas de nível inferior; a distinção entre ponto de vista externo (ou ético-político) e ponto de vista interno (ou jurídico) e a conexa divergência entre justiça e validade; a autonomia e a prevalência do primeiro e em certo grau irredutível de ilegitimidade política com relação a ele das instituições vigentes".
} 
teoria jurídica de validade e de efetividade; e filosofia política (iii). O primeiro logicamente, numa abordagem penal ${ }^{34}$ - estabelece um modelo de estrita legalidade do Sistema Garantista (SG), característico do Estado de Direito, subdividindo-se em três planos: (i.1) um epistemológico de cognição e de poder mínimo; (i.2) um político para aperfeiçoar as liberdades e restringir a violência; e (i.3) um jurídico com um conjunto de vínculos legais estabelecidos para o Estado, no exercício do jus puniendi, para garantir os direitos dos cidadãos. Neste último plano, merece destaque que o próprio Estado determina uma limitação ao seu monopólio legiferante, ou seja, os direitos das pessoas não podem ser modificados pela simples vontade do Estado, ainda que sob o gosto da maioria e da mera legalidade.

O segundo significado mantém a distinção do mundo do ser em relação ao do dever ser, tratando o direito tanto sob uma perspectiva formal quanto substancial. Trata-se de uma possibilidade de crítica do direito, pois permite auferir a legitimidade ou ilegitimidade de um sistema jurídico-penal, e aqui reside a noção de validade de FERRAJOLI. Ora, em apertada síntese, apenas quando estiverem presentes os aspectos formais e substanciais de uma norma, será ela válida. Contrariamente à KELSEN que deriva a validade de uma norma de outra norma, atentendo a anterioriedade e a hierarquia, considerando a legitimidade interna como bastante. Tal postura - segundo FERRAJOLI - é contrária ao garantismo que "[...] requer, ao contrário, a dúvida, o espírito crítico e a incerteza permanente sobre a validade das leis e de suas aplicações [...]"35.

O terceiro e último implica num ônus de justificação externa ao direito e ao Estado, implicando uma separação entre moral e direito. A obervância formal e substancial visa resgatar a possibilidade de garantia efetiva aos sujeitos jurídicos, em relação a todos os direitos fundamentais. Estes são a pedra de toque do Garantismo, já que:

[...] significa precisamente a tutela daqueles valores ou direitos fundamentais, cuja satisfação, mesmo contra os interesses da maioria, constitui o objeto justificante do direito penal, vale dizer, a imunidade dos cidadãos contra a arbitrariedade das proibições e das punições, a defesa dos fracos mediante regras do jogo iguais para todos, a dignidade da pessoa do imputado, e, consequentemente, a garantia da sua liberdade, inclusive por meio do respeito à sua verdade ${ }^{36}$.

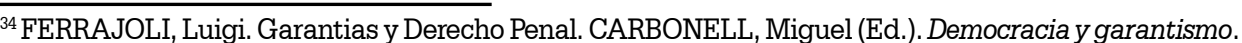
Madrid: Editorial Trotta, 2008, p.192: “Con todo, la acepción prevalente de la palabra 'garantismo' es la de 'garantismo penal'. Es, en efecto, en el âmbito del derecho penal donde el garantismo se ha desarrolado como teoria y como prática jurídica, en oposición, primeiro, a los contundentes legados de la legislación fascista y, después, a las numerosas leyes excepcionales y de emergencia que han terminado reduciendo, en contra de los princípios constitucionales, el ya débil sistema de garantias contra el arbítrio punitivo".

${ }^{35}$ FERRAJOLI, Luigi. Direito e Razão: teoria do garantismo penal. Tradução de Ana Paula Zomer, Fauzi Hassan Choukr, Juarez Tavares et al. São Paulo: RT, 2002, p.685.

${ }^{36}$ FERRAJOLI, Luigi. Direito e Razão: teoria do garantismo penal. Tradução de Ana Paula Zomer, Fauzi Hassan Choukr, Juarez Tavares et al. São Paulo: RT, 2002, p.271.
} 
Deste trecho, deduzem-se duas importantes conseqüências. A primeira de que o Estado não pode ser visto como o absoluto responsável pela outorga dos direitos vitais aos indivíduos, porque estes direitos fundamentais não existindo antes do Estado - que os atribui aos cidadãos - poderiam ser retirados por este a qualquer momento. Justamente aqui reside o perigo da teorização do DPI, pois ao se embasar no funcionalismo sistêmico de LUHMANN trata a sociedade como o conjunto de comunicações (e não de pessoas de carne e osso), sendo a "[...] principal condição para uma sociedade que é respeitosa com a liberdade de atuação é: personalização dos sujeitos"37. Isto autoriza o seguinte raciocínio de JAKOBS: "En la medida en que se le prive de derechos no es tratado-por definición- como persona en Derecho"38.

A condição de inimigo, portanto, é decorrência de uma "autoexclusão facultativa" do indivíduo, ou seja, como membro de uma sociedade deve desenvolver um papel social (sentido funcionalista do termo pessoa), e mais precisamente perante o Direito deve cumprir com seus deveres e gozar de seus direitos ${ }^{39}$. Desta forma, o inimigo é assim considerado em razão de sua auto-exclusão do sistema jurídicopenal, sendo uma escolha deixar ou não este status normativo, ao não "[...] prestar la garantía cognitiva mínima de respeto a la norma, que es, por ello, la mínima exigencia de respeto a los demás como 'personas en Derecho'"40. Ora, o Estado como dono absoluto dos limites e alcances da ingerência na regulação social nesta linha jakobsiniana, acaba por abrir espaço para permitir a restrição e até a retirada de direitos fundamentais. Nesse aspecto, menciona-se o trecho em que fica explícita tal idéia de JAKOBS:

Lo que sucede es que una personalidad real, que dirija la orientación, no puede alcanzarse mediante meros postulados, sino que, al contrario, quien deba ser persona debe 'participar', y eso significa que debe hacer su parte, esto es, garantizar suficiente fidelidad al ordenamiento jurídico. Por consiguiente, la proposición debe ser completada: todo aquél que prometa de modo más o menos confiable fidelidad al ordenamiento jurídico tiene derecho a ser tratado como persona en Derecho. Quien no preste esta promesa de modo creíble será tendencialmente heteroadministrado; se le priva de derechos ${ }^{41}$.

\footnotetext{
${ }^{37}$ JAKOBS, Günther. Sociedade, norma e pessoa: teoria de um direito penal funcional. Tradução de Maurício Antonio Ribeiro Lopes. Barueri: Manole, 2003, p.44-45.

${ }^{38}$ JAKOBS, Günther. Derecho penal del enemigo? Un estudio acerca de los presupuestos de la juridicidad. Traddución de Manuel Cancio Meliá. Panóptica, Vitória, ano 2, n. 11, nov. - fev. 2008, p.206.

${ }^{39}$ RECASENS SICHES, Luis. Tratado General de Filosofia del Derecho. Cuarta edicion. Mexico: Editorial Porrua, 1970, p.244: "En el campo de lo jurídico la palabra 'persona' expresa el sujeto de las relaciones jurídicas, por lo tanto, el sujeto de los deberes jurídicos y de los derechos subjetivos".

${ }^{40}$ POLAINO ORTS, Miguel. Derecho penal del enemigo: desmitificación de un concepto. Lima: Grijley, 2006, p.101.

${ }^{41}$ JAKOBS, Günther. Derecho penal del enemigo? Un estudio acerca de los presupuestos de la juridicidad. Traddución de Manuel Cancio Meliá. Panóptica, Vitória, ano 2, n. 11, p.197-213, nov. - fev. 2008, p.206.
} 
A segunda consequência é que a idéia de democracia para o Garantismo não admite a absolutização da simplista regra da maioria para todas as decisões (democracia política), sob pena de guiar formas de direito penal máximo, apartadas de limites e das garantias fundamentais. Portanto, uma democracia constitucional ou de direito é mais completa, pois não dissocia a maioria e os limites necessários a ela "[...] que hace referencia no a quién puede decidir (la mayoría, en este caso), sino a qué es lo que no puede decidir ninguna mayoría, ni siquiera por unamidad"42.

A seguir, tentar-se-á explicar algumas das significativas conexões do Feindstrafrecht com um direito penal autoritário, decorrente de um "formalismo ético"43 - gerando problemas para a construção de um Direito Penal Garantista como: (4.1) a proximidade com um direito penal de autor (Täterstrafrecht); (4.2) o Direito apenas como legitimação interna (jurídica); (4.3) a sua legitimação para manutenção do Estado de Direito; (4.4) a possibilidade de supressão de garantias; e (4.5) a "neutralidade" e a mera constatação do direito positivo.

\subsection{Lombroso-Mezger-Jakobs, uma análise da proximidade destes discursos com um direito penal de autor (Täterstrafrecht): primeiro retrocesso}

Uma das principais críticas, senão, a mais freqüente delas é a de que o DPI institui um Täterstrafrecht, incriminando pessoas (classes sociais, movimentos sociais, estilos de vida) e não fatos. O que faz dele um exemplo de direito penal de autor é o tratamento dos indivíduos como fontes de perigo, tanto que ele "[...] poderse-ia conjeturar - seria, então, sobretudo o Direito das medidas de segurança aplicáveis a imputáveis perigosos" 4 .

Primeiramente, deve ser destacado que a proposta de JAKOBS de cindir o Direito Penal em duas vertentes não é inédita ${ }^{45}$, sendo inclusive ponto destacado por FERRAJOLI nos seguintes termos: "Como suele suceder, en derecho penal nunca se inventa nada nuevo. El esquema del 'enemigo del pueblo' de estaliniana memoria y por otra parte, el modelo penal nazi del 'tipo normativo de autor'(Tätertyp)"46. Neste aspecto, também se destacam os nomes de Cesare LOMBROSO e Edmund MEZGER.

\footnotetext{
${ }^{42}$ FERRAJOLI, Luigi. Garantias y Derecho Penal. CARBONELL, Miguel (Ed.). Democracia y garantismo. Madrid: Editorial Trotta, 2008, p.197.

${ }^{43}$ FERRAJOLI, Luigi. Direito e Razão: teoria do garantismo penal. Tradução de Ana Paula Zomer, Fauzi Hassan Choukr, Juarez Tavares et al. São Paulo: RT, 2002, p.172: "[...] legalismo ou formalismo ético, que, por sua vez, caracteriza-se por uma concepção formal e jurídica (não apenas da validade, mas, também) da justiça, e via de conseqüência, pela assunção do direito positivo como valor ético ao qual se deve adesão não apenas por razões jurídicas, mas também por razões políticas ou morais".

${ }^{44}$ SILVA SÁNCHEZ, Jesús-Maria. A expansão do direito penal: aspectos da política criminal nas sociedades pós-industriais. Tradução de Luiz Otavio de Oliveira Rocha. São Paulo: RT, 2002, p.150.

${ }^{45}$ D'ÁVILA, Fábio Roberto. O inimigo no Direito Penal contemporâneo. Algumas reflexões sobre o contributo crítico de um Direito Penal de base onto-antropológica. GAUER, Ruth Maria Chittó (Coor.). Sistema Penal e Violência. Rio de Janeiro: Lumen Juris, 2006, p.96, nota de rodapé 4.

${ }^{46}$ FERRAJOLI, Luigi. El "Derecho Penal del Enemigo" y la disolución del Derecho Penal. CARBONELL, Miguel (Ed.). Democracia y garantismo. Madrid: Editorial Trotta, 2008, p.237.
} 
LOMBROSO, espoente mais conhecido da Escola Positiva italiana, em sua famigerada obra, "O homem delinqüente", faz uso constante do termo "inimigo", o que permite já notar algumas aproximações dos textos de JAKOBS com aquele. Além disso, a idéia de perigo social procura identificar uma minoria perigosa que deve ser apartada da sociedade, semelhantemente ao sustentado no Feindstrafrecht quando é defendida a submissão do inimigo àlgumas medidas destinadas a estancar o perigo personificado, já que representa ele "[...] solo fuente de peligro o, con otras palavras, enemigo del bién jurídico" ${ }^{47}$. Além disso, num trecho dessa clássica obra de LOMBROSO, resta clara a separação maniqueísta entre indivíduos perigosos e bons, pois "[...] com efeito, a detenção perpétua, a pena capital, que são as últimas palavras de nossas pesquisas, seriam impraticáveis em relação a um número grande de homens, mas podemos aplicá-las muito bem a um número restrito"48. Importante mencionar também a observação de Vera Regina Pereira de ANDRADE no sentido de que: "Estabelece-se desta forma uma linha divisória entre o mundo da criminalidade - composta por uma 'minoria' de sujeitos potencialmente perigosos e anormais - e o mundo da normalidade - representada pela 'maioria' da sociedade" 49 .

MEZGER, um dos principais nomes da dogmática jurídico-penal alemã da primeira metade do século XX, em 1943 sustentou mais de um Direito Penal em seus informes para a confecção do Projeto de Lei sobre os Estranhos à Comunidade do Governo Nacional-Socialista ${ }^{50}$. Sobre a divisão do Direito Penal no tema presente, MUÑOZ CONDE atribui " [...] a los que asumen esta distinción como inevitable aclarar lo que se quiere decir con la por lo demás bastante ambigua expresión "Derecho penal del enemigo" y cuáles serían los límites que el mismo debería tener, si es que tiene alguno" 51 .

Importante salientar que a proposta do Direito Penal do Inimigo não é uma recepção in totum dessas idéias supramencionadas, tratando-se de fundamentações teóricas diversas, historicamente situadas, conforme advertência de POLAINO $\mathrm{ORTS}^{52}$. Apesar de se reconhecer que semelhança não significa igualdade, tal

${ }^{47}$ JAKOBS, Günther. Criminalización em el estadio previo a la lesión de un bien juridico. Estudios de Derecho Penal. Traducción de Enrique Peñaranda Ramos, Carlos J. Suárez González y Manuel Cancio Meliá. Madrid: Civitas, 1997, p.295.

${ }^{48}$ LOMBROSO, Cesare. O homem criminoso. Tradução de Maria Carlota Carvalho Gomes. Rio de Janeiro: Editora Rio, 1983, p.xix.

${ }^{49}$ ANDRADE, Vera Regina Pereira de. A ilusão de Segurança Jurídica: Do controle da violência à violência do controle penal. $2^{\mathrm{a}}$ ed. Porto Alegre: Livraria do Advogado Editora, 2003, p.67.

${ }^{50}$ MUÑOZ CONDE, Francisco. Edmund Mezger e o Direito Penal de seu tempo. $4^{\mathrm{a} e d .}$ Tradução de Paulo César Busato. Rio de Janeiro: Lumen Juris, 2005, p.151-152: "Segundo o Projeto no futuro haverá dois (ou mais) 'Direitos penais', - Um Direito Penal para a generalidade (no que em essência seguirão vigentes os princípios que o regeram até agora) e - Um Direito Penal (completamente diferente) para os grupos especiais de determinadas pessoas, como, por exemplo, os 'delinqüentes por tendência'". ${ }^{51}$ MUÑOZ CONDE, Francisco. El nuevo Derecho penal autoritário. In: LOSANO, Mario G.; MUÑOZ CONDE, Francisco (Coord.). El Derecho ante la globalización y el terrorismo. Valencia: Tirant lo blanch, 2004, p.173. ${ }^{52}$ POLAINO ORTS, Miguel. Derecho penal del enemigo: desmitificación de un concepto. Lima: Grijley, 2006, p.214, rodapé de número 43: "En ningún caso se refiere el autor alemán a 'personas identificables 
proposta não deixa de ser uma manifestação de um direito penal de autor, pois o inimigo é tratado como uma não-pesso ${ }^{53}$ que "[...] sobre a configuração normativa da sociedade predomina a necessidade de segurança cognitiva e ao 'inimigo' se lhe define simplesmente como 'não pessoa' ('Feinde sind aktuell Unpersonen')"54.

Desta forma, mesmo por fundamentações diversas das de LOMBROSO e de MEZGER, notam-se similitudes com o Direito Penal do Inimigo, e este acabou por traçar " $[. .$.$] un puente entre la guerra y el Derecho penal y Günther Jakobs [...]$ ha sentado las bases conceptuales, intelectuales y filosóficas de um Derecho penal que, em realidad, no es 'Derecho', sino guerra contra los malos y los peligrosos" ${ }^{55}$.

\subsection{O Direito como mera legitimação interna ou jurídica: segundo retrocesso}

O aparato teórico luhmaniano adotado por JAKOBS, torna coerente o DPI no Estado de Direito (no sentido débil ou formal ${ }^{56}$ ), já que se fundamenta sobre si mesmo (legitimação exclusivamente interna ou jurídica).

Encontra-se aqui uma primeira incompatibilidade da teoria sistêmicofuncional (e do Direito Penal do Inimigo que parte deste marco teórico) com o Garantismo: os pontos de vista interno e externo (legitimação interna e justificação externa). Enquanto para o último, o direito deve se justificar a partir de um pontode-vista externo ou de uma legitimação substancial e não apenas por uma legitimidade interna/jurídica, na teoria sistêmica de Niklas LUHMANN o direito se auto-legitima. Portanto, o Garantismo ao defender que a base de legitimidade do direito decorre também de fatores políticos, está claro que o direito não se sustentaria por si só, nem se autodeterminaria, como quer o pensamento sistêmico funcional. Para LUHMANN, o Direito Positivo estabelece as condições de sua própria validez, se legitimando como Direito. Como ocorre com todos os Sistemas Sociais, a legitimação da atuação do sistema jurídico é dada pelo próprio sistema

incluso por características físicas', sino a algo muy diferente, a saber: la producción de inseguridad cognitiva en la vigencia de la norma, de manera que se impide el desarrollo de la personalidad en Derecho por parte de los ciudadanos, y - con ello - la convivencia social".

${ }^{53}$ AMARAL, Cláudio do Prado. Bases Teóricas da Ciência Penal Contemporânea: dogmática, missão do direito penal e política criminal na sociedade de risco. São Paulo: IBCCRIM, 2007, p.126: "São indivíduos que, pasmem, Jakobs designa como 'não-pessoas'. O 'inimigo' é um indivíduo que se recusa a ingressar no estado de cidadania, e por isso não pode particiapar dos benefícios do conceito de pessoa".

${ }^{54}$ MUÑOZ CONDE, Francisco. Edmund Mezger e o Direito Penal de seu tempo. $4^{\mathrm{a} e d .}$ Tradução de Paulo César Busato. Rio de Janeiro: Lumen Juris, 2005, p.68.

${ }^{55}$ PRITTWITZ, Cornelius. Derecho Penal del enemigo: ¿ Anális crítico o programa del Derecho Penal? In: MIR PUIG, Santiago, CORCOY BIDASOLO, Mirentxu (Dir.). La política criminal en Europa. Barcelona: Atelier, 2004, p.108.

${ }^{56}$ FERRAJOLI, Luigi. Passado y futuro del Estado de Derecho. CARBONELL, Miguel (Org.) Neoconstitucionalismo(s). Madrid: Trotta, 2003, p.13: "En sentido lato, débil o formal, 'Estado de Derecho' designa cualquier ordenamiento en el que los poderes públicos son conferidos por la ley y ejercitados en las formas y con los procedimientos legalmente estabelecidos". 
(toda legitimação é auto-legitimação). Em suma: a legalidade é a única legitimidade ${ }^{57}$. Eis o paradoxo da validade ou constituição do Direito: o Direito positivo tem validade porque ele poderia ser modificado através de uma decisão jurídica ${ }^{58}$. Sobre tal fundamentação auto-referente que faz do indivíduo um subsistema físico-psíquico FERRAJOLI adverte que:

O ponto de vista da justificação externa, também neste caso, desaparece, sujeitando-se inteiramente ao ponto de vista interno, pouco importando se este, em vez de identificar-se com os costumes do Estado ou com qualquer pretensa moralidade intrínseca ao direito, transformou-se em simples instância funcional de autoconservação do sistema político ${ }^{59}$.

O Garantismo enquanto proposta simultânea de teoria jurídica, modelo normativo e de filosofia política busca seus fundamentos concomitantemente no âmbito social e jurídico, sem acorrentar-se, exclusivamente, em parâmetros dogmáticos ou extradogmáticos. A riqueza da Teoria Garantista advém de seu caráter crítico, decorrente do ponto de vista externo, e não deixa de ser uma teoria procedimental que busca suas bases no social. FERRAJOLI, portanto, considera a Teoria Funcional Sistêmica de LUHMANN um exemplo de "legalismo ou formalismo ético" "[...] em razão daquela perversão ideológica e autoritária do positivismo jurídico segundo a qual o direito se autojustifica, bastando para tanto a sua forma e a sua fonte, independentemente do seu conteúdo" ${ }^{60}$.

O perigo dessas teorias que trabalham apenas com a legitimidade interna (jurídica) é ignorar os conteúdos das normas, legitimando absurdos como os frequentes exemplos de materializações do Feindstrafrecht como as prisões preventivas, os tipos penais de autor, os crimes de infração de dever (Pflichtdelikte), a antecipação de barreiras punitivas, a punibilidade de atos preparatórios, dentre outras. Tanto é que JAKOBS ao partir da premissa de que o Direito constitui-se como um "sistema autopoiético" ${ }^{61}$, no qual produz suas normas de forma autônoma

\footnotetext{
${ }^{57}$ Cfr. em: LUHMANN, Niklas. Sociologia do Direito I. Tradução de Gustavo Bayer. Rio de Janeiro: Edições Tempo Brasileiro, 1983, pp. 225 e ss; LUHMANN, Niklas. Sociologia do Direito II. Tradução de Gustavo Bayer. Rio de Janeiro: Edições Tempo Brasileiro, 1985, pp. 7-70; LUHMANN, Niklas. A restituição do décimo segundo camelo: do sentido de uma análise sociológica do Direito. In: ARNAUD, A; LOPES JR., D. Niklas Luhmann: do sistema social à sociologia jurídica. Rio de Janeiro: Lumen Juris, 2004, pp. 35 e ss; LUHMANN, Niklas. El Derecho como sistema social. In: GÓMEZ-JARA DÍEZ, Carlos (ed.). Teoría de sistemas y Derecho penal, p. 84.

${ }^{58}$ LUHMANN, Niklas. A restituição do décimo segundo camelo: do sentido de uma análise sociológica do Direito, p. 75.

${ }^{59}$ FERRAJOLI, Luigi. Direito e Razão: teoria do garantismo penal. Tradução de Ana Paula Zomer, Fauzi Hassan Choukr, Juarez Tavares et al. São Paulo: RT, 2002, p.222.

${ }^{60}$ FERRAJOLI, Luigi. Direito e Razão: teoria do garantismo penal. Tradução de Ana Paula Zomer, Fauzi Hassan Choukr, Juarez Tavares et al. São Paulo: RT, 2002, p.208.

${ }^{61}$ FERRAJOLI, Luigi. Direito e Razão: teoria do garantismo penal. Tradução de Ana Paula Zomer, Fauzi Hassan Choukr, Juarez Tavares et al. São Paulo: RT, 2002, p.706: "Para as doutrinas autopoiéticas, o Estado é um fim, e encarna valores ético-políticos de características supra-social e supra-individual cuja conservação e reforço para o direito e os direitos hão de ser funcionalizados".
} 
em relação ao ambiente e aos outros sistemas da sociedade, cada Estado tem os mecanismos próprios para expurgar do sistema jurídico aquelas normas incompatíveis (inconstitucionais). Assim, caberia ao Supremo Tribunal Federal (STF), por exemplo, no caso brasileiro, dizer o que é ou não é direito. Também advoga por uma democracia formal ao legitimar todo e qualquer diploma legislativo, pois nas palavras de POLAINO ORTS: "¿Qué mayor legitimación existe si son aprobadas por un Parlamento democrático, que refleja la voluntad y la soberanía de todos los ciudadanos?" ${ }^{2}$. Sobre essas justificações puramente jurídicas (ignorando uma legitimidade e uma democracia substanciais), FERRAJOLI diz que:

[...] são, nos mais variados modos, apologéticas das concretas escolhas e dos conteúdos contingentes do direito penal positivo, em relação ao qual desenvolvem uma função de legitimação ideológica, identificando-o, em maior ou menor escala, com a justiça; ao mesmo tempo são solidárias com modelos de direito penal máximo e tendencialmente ilimitado ${ }^{63}$.

\subsection{A legitimação da violência estatal para manutenção do Estado de Direito? Um terceiro retrocesso}

A busca desmedida pela ordem e segurança do $\mathrm{DPI}^{64}$, incorre numa cristalina incompatibilidade com um SG por buscar a manutenção da ordem jurídica a qualquer custo, mesmo diante das elevadas "cifras da injustiça" ${ }^{65}$. O problema aqui se centra na (in) compatibilidade do Direito Penal do Inimigo com o Estado Democrático de Direito e suas estruturas, e se estaria este último, em sua conjuntura atual, preparado para enfrentar a criminalidade atual, eminentemente aquela oriunda de atos terroristas e da criminalidade organizada. Em outras palavras, seria o Direito Penal do Inimigo um mal necessário do Estado Democrático de Direito ou a pior forma de terrorismo, aquele praticado pelo Estado? JAKOBS tenta justificar que "[...] a única forma de 'salvar' o 'direito penal do cidadão' com todas as suas garantias, impedindo a sua contaminação por medidas de um direito de exceção que, na verdade, estariam orientadas ao inimigo, é reconhecendo o Feindstrafrecht [...]"66. Tal bifurcação é a

\footnotetext{
${ }^{62}$ POLAINO ORTS, Miguel. Derecho penal del enemigo: desmitificación de un concepto. Lima: Grijley, 2006, p.198.

${ }^{63}$ FERRAJOLI, Luigi. Direito e Razão: teoria do garantismo penal. Tradução de Ana Paula Zomer, Fauzi Hassan Choukr, Juarez Tavares et al. São Paulo: RT, 2002, p.221.

${ }^{64}$ JAKOBS, Günther. Ciência do Direito e Ciência do Direito Penal. Tradução de Maurício Antonio Ribeiro Lopes. Barueri: Manole, 2003, p.10: "Radbruch falou com acerto do valor irrenunciável da segurança jurídica invocando para isso a expressão de Goethe de que poderia suportar melhor uma injustiça do que a desordem"

${ }^{65}$ FERRAJOLI, Luigi. Direito e Razão: teoria do garantismo penal. Tradução de Ana Paula Zomer, Fauzi Hassan Choukr, Juarez Tavares et al. São Paulo: RT, 2002, pp.168-169: "Porém, a cifra da injustiça, como facilmente perceptível na análise até o momento realizada, é, principalmente, o produto da carência normativa ou da não efetividade prática das garantias penais e processuais, que acabam por prestar-se ao arbítrio e ao erro".

${ }^{66}$ D'ÁVILA, Fábio Roberto. O inimigo no Direito Penal contemporâneo. Algumas reflexões sobre o contributo crítico de um Direito Penal de base onto-antropológica. GAUER, Ruth Maria Chittó (Coor.). Sistema Penal e Violência. Rio de Janeiro: Lumen Juris, 2006, p.96.
} 
forma que JAKOBS encontrou para promover a proteção das garantias fundamentais dos cidadãos no Estado Democrático de Direito. Contudo, uma das mais divulgadas críticas ao DPI consiste nas rachaduras provocadas por este modelo criminal nas balizas do Estado de Direito. Inclusive, na introdução da obra "O inimigo no Direito Penal", Eugênio Raúl ZAFFARONI manifesta-se no seguinte sentido: "Este ensaio aborda a dialética entre o Estado de direito e o de polícia, traduzida no campo penal na admissão, mais ampla ou mais restrita, do tratamento punitivo a seres humanos, privados da condição de pessoas" ${ }^{\prime 67}$.

Isto se justificaria porque diante de alguns ordenamentos jurídicos democráticos que possuem uma amálgama dessas duas categorias, nota-se um aumento da insegurança na aplicação do Direito Penal, e o DPI "[...] no es una regulación para la aniquilación ilimitada, sino, en un Estado de Derecho administrado con inteligencia, una ultima ratio que es aplicada conscientemente en cuanto excepción, como algo que no es idóneo para su uso permanente" ${ }^{68}$. Contudo, ao invés de ser um remédio para o Estado de Direito, o DPI provoca o óbito de todo o direito penal com "[...] la confusión entre derecho penal y guerra: nada más destructivo del derecho y del Estado de derecho"69. E pior, as mutações observadas em alguns Estados de Direito têm coadunado com este paradigma penal de emergência, conforme palavras de José Joaquim Gomes CANOTILHO:

\begin{abstract}
O Estado de direito democrático-constitucinal volta a albergar o estado de exceção como estado de necessidade sem as restrições do 'direito de necessidade'. Um direito penal de permanência com as mutações naturais da sua historicidade evolui para um direito penal de emergência ${ }^{70}$.
\end{abstract}

Notável o retrocesso para o Garantismo que se preocupa justamente em minimizar a violência e ampliar as esferas de liberdade, enquanto o DPI intenta otimizar a violência da pior forma possível: legitima e amplia as formas de violência do Estado contra as pessoas, data venia, contra as não-pessoas ${ }^{71}$. O Feindstrafrecht guarda similitudes e até mesmo fortes laços com aqueles modelos de direito penal

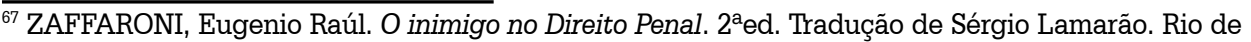
Janeiro: Revan, 2007, p.9.

${ }^{68}$ JAKOBS, Günther. Derecho penal del enemigo? Un estudio acerca de los presupuestos de la juridicidad. Traddución de Manuel Cancio Meliá. Panóptica, Vitória, ano 2, n. 11, nov. - fev. 2008, p.207.

${ }^{69}$ FERRAJOLI, Luigi. El "Derecho Penal del Enemigo" y la disolución del Derecho Penal. CARBONELL, Miguel (Ed.). Democracia y garantismo. Madrid: Editorial Trotta, 2008, p.239.

${ }^{70}$ CANOTILHO, José Joaquim Gomes. Justiça Constitucional e Justiça Penal. Revista Brasileira de Ciências Criminais, São Paulo, n.58, jan./fev.2006, p.334.

${ }^{71}$ JAKOBS, Günther. Personalidad y exclusión en derecho penal. In: MONTEALEGRE LYNETT, Eduardo (Coord.). El Funcionalismo en Derecho Penal. Libro Homenaje al professor Günther Jakobs. Bogotá: Universidad Externado de Colombia, 2003, p.86: "[...] conduce a un derecho penal que no se dirige a personas sino a individuos los cuales en relación con un determinado comportamiento han de ser estimulados, en caso necesario desconectados y, ya en casos extremos, combatidos: derecho penal de enemigos".
} 
autoritários, negando um Estado de Direito forte ou substancial ${ }^{72}$ (indispensável para o Garantismo penal) porque acaba por reprimir não "[...] tanto ou não apenas determinados comportamentos, senão atitudes ou situações subjetivas de imoralidade, de perigosidade ou de hostilidade ao ordenamento, para além de sua exteriorização em manifestações delituosas concretas" ${ }^{\prime 3}$.

Por fim, as rachaduras provocadas por esta construção jakobsiniana no Direito Penal democrático, laico e liberal são permanentes, devendo ser rechaçada, pois "[...] em un Estado democrático de derecho no deberia existir más violencia legal que la estrictamente necesaria para controlar otras formas de violência[...]"74. A pretensão de JAKOBS em se reconhecer e legitimar o DPI para salvaguardar as estruturas garantistas de um Direito Penal do Cidadão é duramente criticada por Cornelius PRITTWITZ: "[...] la propuesta formulada por Jakobs en virtud de la cual el expreso reconocimiento del 'Derecho penal del enemigo' podría salvaguardar el 'Derecho penal del ciudadano' carece de fundamento empírico alguno"75. E mais, ZAFFARONI chama a atenção para o fato de que "[...] Jakobs deve ser criticado pela introdução de elementos próprios do Estado absoluto no interior do Estado de direito, sem se dar conta que isso o implode"76. Além da crítica à construção de JAKOBS sobre o Direito Penal enquanto reflexo da identidade social, GRECO dispara ainda que no Estado de Direito "[...] a identidade normativa de uma sociedade não apresenta valor qualquer. $O$ que interessa não é se uma sociedade é idêntica a si mesma, e sim se ela consegue garantir o respeito à dignidade humana e aos direitos fundamentais do cidadão"77.

\subsection{A supressão de garantias e ofensa aos direitos fundamentais: quarto retrocesso}

Neste ínterim a questão está em se considerar ou não o DPI como absoluto, ora, será que em nenhuma hipótese podem ser flexibilizados os direitos de um criminoso/investigado? PRITTWITZ adianta que "[...] nunca Jakobs y tampoco en

\footnotetext{
${ }^{72}$ FERRAJOLI, Luigi. Passado y futuro del Estado de Derecho. CARBONELL, Miguel (Org.) Neoconstitucionalismo(s). Madrid: Trotta, 2003, p.13: “'[...] fuerte o sustancial, 'Estado de Derecho' designa, en cambio, solo aquellos ordenamientos en los que los poderes públicos están, además, sujetos a la ley (y, por tanto, limitados o vinculados por ella), no solo en lo relativo a las formas, sino también en los contenidos".

${ }^{73}$ FERRAJOLI, Luigi. Direito e Razão: teoria do garantismo penal. Tradução de Ana Paula Zomer, Fauzi Hassan Choukr, Juarez Tavares et al. São Paulo: RT, 2002, p.80.

${ }^{74}$ FERRAJOLI, Luigi. La legalidad violenta. CARBONELL, Miguel (Ed.). Democracia y garantismo. Madrid: Editorial Trotta, 2008, p.175.

${ }^{75}$ PRITTWITZ, Cornelius. Derecho Penal del enemigo: ¿ Anális crítico o programa del Derecho Penal? In: MIR PUIG, Santiago, CORCOY BIDASOLO, Mirentxu (Dir.). La política criminal en Europa. Barcelona: Atelier, 2004, p.119.

${ }^{76}$ ZAFFARONI, Eugenio Raúl. O inimigo no Direito Penal. $2^{a}$ ed. Tradução de Sérgio Lamarão. Rio de Janeiro: Revan, 2007, p.160.

${ }^{77}$ GRECO, Luís. Cumplicidade através de ações neutras. A imputação objetiva na participação. Rio de Janeiro: Renovar, 2004, p.39.
} 
el año 1985 ha defendido un modelo garantista eterno e inalterable"78. Tal postura parece decorrer de uma provocação feita por um dos principais teóricos de seus escritos: LUHMANN. Este escreveu em 1993 um artigo intitulado "Are There Still Indispensable Norms in Our Society?", no qual levanta a seguinte questão:

Imagine: You are a high-level law-enforcement officer. In your country - it could be Germany in the not-too-distant future - there are many left- and right-wing terrorists every day there are murders, fire-bombings, the killing and injury of countless innocent people. You have captured the leader of such a group. Presumably, if you tortured him, you could save many lives - 10,100, 1000 - we can vary the situation. Would you do it? ${ }^{79}$.

Importante aqui mencionar que a possibilidade de supressão de garantias e direitos fundamentais cinge-se na "esfera do indecidível" ${ }^{80}$, peculiaridade da democracia constitucional ou de direito da Teoria Garantista. Ora, este conceito de FERRAJOLI é uma blindagem dos direitos fundamentais em face da vontade da maioria. Segundo ele as Constituições estabelecem como vínculos e limites a maioria tanto a igualdade dos cidadãos - independentemente de serem desviados ou não quanto à garantia de seus direitos fundamentais, principalmente a vida e a liberdade pessoal, as quais não podem ser sacrificadas por nenhuma vontade da maioria, nem por interesse geral, nem por algum bem comum ou público ${ }^{81}$. Portanto, o código binário penal elevado ao extremo (cidadão/inimigo; pessoa/não-pessoa) por JAKOBS não pode ser aceito por um Estado de Direito substancial, no qual as garantias fundamentais de todos são invioláveis, sejam ou não "inimigos".

Exemplos de ofensa aos princípios constitucionais penais da igualdade e da presunção de inocência não faltam nas legislações de vários Estados tidos como democráticos, sendo que o tratamento dos delinquentes como inimigos, destacadamente no caso dos terroristas, "[...]tiene capacidad bastante para arrolar todas las garantias del derecho penal, desde el principio de legalidad al de

\footnotetext{
${ }^{78}$ PRITTWITZ, Cornelius. Derecho Penal del enemigo: ¿ Anális crítico o programa del Derecho Penal? In: MIR PUIG, Santiago, CORCOY BIDASOLO, Mirentxu (Dir.). La política criminal en Europa. Barcelona: Atelier, 2004, p.111-112.

${ }^{79}$ LUHMANN, Niklas. Are There Still Indispensable Norms in Our Society? Translated by Todd Cesaratto. Soziale Systeme

14 (2008), Heft 1, S. 18-37. Disponível em: < http://www.soziale-systeme.ch/pdf/sozsys_12008 luhmann-norms.pdf >. Acesso em: 10.set.2009, p.18.

${ }^{80}$ FERRAJOLI, Luigi. Jurisdicción y Democracia. CARBONELL, Miguel (Ed.). Democracia y garantismo. Madrid: Editorial Trotta, 2008, p.212: "Esa esfera de lo no decidible - 'qué cosa' no es lícito decidir (o no decidir)- no es sino lo que en las constituciones democráticas se ha convenido sustraer a la voluntad de la mayoria".

${ }^{81}$ FERRAJOLI, Luigi. Garantias y Derecho Penal. CARBONELL, Miguel (Ed.). Democracia y garantismo. Madrid: Editorial Trotta, 2008, p.197.
} 
culpabilidad, desde la presunción de inocencia hasta la carga de la prueba y los derechos de la defensa" ${ }^{2}$. Inclusive se chega ao absurdo de não ser possível falar em violação de garantia, conforme Bernd MÜSSIG salienta "[...] la desformalización ínsita en la concepción de um Derecho penal del enemigo conduce consecuentemente a la ausencia de toda protección juridico-processual cuando concurra cualquier sospecha o indicio" ${ }^{83}$. A título de exemplo, como defender um investigado ou réu que é visto como deturpador da ordem civil e do pacto social, qual a defesa (se é que se possa imaginar) para um inimigo da sociedade? Nenhuma para o acusado (ou melhor, condenado, pois já há um juízo valorativo embutido nesta terminologia adotada), sob a justificativa de uma (pseudo) segurança jurídica ${ }^{84}$.

Além disso, ao permitir a supressão de garantias fundamentais do indivíduo tanto de índole material quanto processual ${ }^{85}$ pelo abandono do Direito, e de certa forma do Estado pelo inimigo (autoexclusão para JAKOBS da condição de pessoa em Direito ${ }^{86}$ ) não leva em consideração o fato de que em muitas situações, nenhuma dessas instituições do Estado chegou ao indivíduo. Conclusivamente, exigir do mesmo, um comportamento lícito e compatível como aquele é, no mínimo, um ato hipócrita, desumano e surreal ${ }^{87}$.

\footnotetext{
${ }^{82}$ FERRAJOLI, Luigi. El "Derecho Penal del Enemigo" y la disolución del Derecho Penal. CARBONELL, Miguel (Ed.). Democracia y garantismo. Madrid: Editorial Trotta, 2008, p.236.

${ }^{83}$ MÜSSIG, Bernd. Derecho Penal del enemigo: concepto y fatídico presagio. Algunas tesis. Derecho Penal del enemigo: el discurso penal de la exclusión.v2.Buenos Aires: Editorial IbdeF, 2006, p.389. ${ }^{84}$ FERRAJOLI, Luigi. El "Derecho Penal del Enemigo" y la disolución del Derecho Penal. CARBONELL, Miguel (Ed.). Democracia y garantismo. Madrid: Editorial Trotta, 2008, p.248: "[...] la opción por la violencia y por la exclusión, bajo la enseña de la oposición amigo/enemigo, y consecuentemente por la demolición de las liberdades fundamentales mismas como precio necesario de una ilusória seguridad".

${ }^{85}$ MÜSSIG, Bernd. Derecho Penal del enemigo: concepto y fatídico presagio. Algunas tesis. Derecho Penal del enemigo: el discurso penal de la exclusión.v2.Buenos Aires: Editorial IbdeF, 2006, p.389: "Las consecuencias de un Derecho penal del enemigo para el proceso penal son imprevisibles (normativamente; cognitivamente lo son, y mucho)" .

${ }^{86}$ JAKOBS, Günther. Personalidad y exclusión en derecho penal. In: MONTEALEGRE LYNETT, Eduardo (Coord.). El Funcionalismo en Derecho Penal. Libro Homenaje al professor Günther Jakobs. Bogotá: Universidad Externado de Colombia, 2003, p.73: "Como derecho original y deber original se puede contemplar la facultad abstracta de adquirir derechos y deberes concretos: es persona quien es capaz jurídicamente. Por consiguiente, está excluido del ámbito de las personas aquél que no puede "disfrutar" de ningún derecho ni soportar ningún deber; está parcialmente excluido quien no participa de determinados derechos y deberes".

${ }^{87}$ APONTE, Alejandro. Derecho Penal del Enemigo VS. Derecho Penal del Ciudadano. CANCIO MELIÁ, Manuel; GÓMEZ-JARA DÍEZ, Carlos (Coords.). Derecho Penal del Enemigo: El discurso penal de la exclusión. Vol.1. Madrid/Buenos Aires: Edisofer y IBdeF, 2006, vol. 1, p.181: "Se trataría de analisar si el Estado mismo propicia un respeto al Derecho, o si es él, en cambio, y sus instituciones, los primeros que no respetan el ordem jurídico: un Estado que no propicia la socialización en el Derecho, no está muy legitimado para exigir el respeto al ordem jurídico y castigar tan duramente a quien no lo hace".
} 


\subsection{A "neutralidade" do Direito Penal do Inimigo e a sua falácia naturalista: quinto retrocesso}

Primeiramente, a escolha pelo adjetivo "inimigo" é, talvez, a crítica mais contundente a JAKOBS, pois ainda que o mesmo apenas refletisse e fizesse uma constatação fática (um juízo de fato, apurativo, analítico) das legislações penais contemporâneas, tal terminologia jamais teria o condão de ser neutra. Contudo, há quem defenda o emprego do termo "inimigo" de uma forma valorativamente neutra, pois apenas descreve um fenômeno político criminal atual, não tendo o intuito de emitir nenhum juízo de valor, seja ele positivo ou negativo. Argumenta-se que além do fato de ser "[...] como todos los nombres, una convención lingüística, que no prejuzga la imputación del sentido de dicho término"88.

Desta forma, ainda que seja sustentada tal "neutralidade" como uma das características do Direito Penal do Inimigo, indiscutível que "a terminologia é o momento propriamente poético do pensamento, então as escolhas terminológicas nunca podem ser neutras"89. A neutralidade decorrente do Direito enquanto ciência é transplantada para a categoria do direito penal do inimigo, influênciada pelo pensamento de KELSEN ${ }^{90}$. Desta forma, ao considerar o Direito como ciência autônoma, adotando uma justificação interna tão-somente (jurídica), JAKOBS através do Feindstrafrecht acaba por presumir uma legitimidade a priori do direito penal positivo: "O abandono do ônus da justificação em razão do seu caráter não científico, conduziu-os, com efeito, a naturalizar o direito positivo e a obliterar o problema filosófico-político da sua justificação externa, e, portanto, dos seus limites e das suas funções" 1 .

Essa suposta neutralidade dessa construção (assim como da própria ciência) permite a contemplação de construções teóricas que foram nefastas para a humanidade, tais quais as teorias lombrosianas e de MEZGER como salientado acima. Mesmo ressaltada a coerência teórica e metodológica adotada por JAKOBS, PRITTWITZ afirma que "o conceito de 'não-pessoa' não mais pode ser usado após $1945^{192}$. Rechaçado o 'relativismo' e a 'proporcionalidade' do DIP, claro fica que não é

${ }^{88}$ POLAINO ORTS, Miguel. Derecho penal del enemigo: desmitificación de un concepto. Lima: Grijley, 2006, p.95.

${ }^{89}$ AGAMBEN, Giorgio. Estado de exceção. Tradução de Iraci D. Poleti. $2^{\mathrm{a} e d . ~ S a ̃ o ~ P a u l o: ~ B o i t e m p o, ~}$ 2007, p.15.

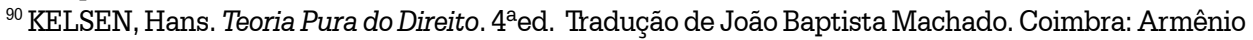
Amado Editor, 1976, p.125: "Na medida em que a ciência jurídica em geral tem de dar resposta a questão de saber se uma conduta concreta é conforme ou é contrária ao Direito, a sua resposta apenas pode ser uma afirmação sobre se essa conduta é prescrita ou proibida, cabe ou não na competência de quem a realiza, é ou não permitida, independentemente do facto de o autor da afirmação considerar tal conduta como boa ou má moralmente, independentemente de ela merecer a sua aprovação ou desaprovação".

${ }^{91}$ FERRAJOLI, Luigi. Direito e Razão: teoria do garantismo penal. Tradução de Ana Paula Zomer, Fauzi Hassan Choukr, Juarez Tavares et al. São Paulo: RT, 2002, p.185.

${ }^{92}$ PRITTWITZ, Cornelius. O Direito Penal entre Direito Penal do Risco e Direito Penal do Inimigo: tendências atuais em direito penal e política criminal. Tradução de Helga Sabotta de Araújo e Carina Quito (Coord.). Revista Brasileira de Ciências Criminais, São Paulo, n.47, mar./abr.2004, p.43. 
possível um conceito limitado de inimigo. A relativa despersonalização do indivíduo, responsável por tolher algumas garantias processuais e materiais penais, e, às vezes, trazer restrições somente neste âmbito do Direito acaba por não convencer, já que conforme ZAFFARONI "[...] esta tática de contenção está destinada ao fracasso, porque não reconhece que para os teóricos - e sobretudo para os práticos - da exceção, esta sempre invoca uma necessidade que não conhece lei nem limites" ${ }^{93}$.

Recuperando as concepções do DPI trazidas no segundo item deste trabalho, notável que JAKOBS não deixa claro em seus escritos quando está descrevendo e quando está prescrevendo ${ }^{94}$, o que não deixa de ser um ato de irresponsabilidade, no mínimo, já que tal categoria tão severa não poderia ser utilizada de qualquer modo ${ }^{95}$. Quando se pronuncia ou se lê o termo inimigo, a reação lógica é questionar: inimigo de quem? Tratando-se de uma ciência como o Direito Penal, tais escolhas trazem reflexos turbulentos na vida social (e não os soluciona como pensa o autor alemão), o que se deveria refletir com mais cautela, não se preocupando apenas com o aspecto abstrato-científico de tal teoria ${ }^{96}$.

Inclusive, FERRAJOLI assevera que: "[...] en la teoría política y em la teoria jurídica no siempre - más bien casi nunca - se distingue analíticamente el estatuto diverso de los dos discursos, descriptivo en um caso, normativo en el otro" ${ }^{97}$. Disso, o que é mais preocupante no âmbito do tema aqui analisado é a passagem do sentido descritivo - realizada cegamente ou não por JAKOBS - para o normativo ${ }^{98}$, incorrendo numa nítida "falácia naturalista" 99 . Neste sentido, conforme finaliza

93 ZAFFARONI, Eugenio Raúl. O inimigo no Direito Penal. $2^{a}$ ed. Tradução de Sérgio Lamarão. Rio de Janeiro: Revan, 2007, p.161.

${ }^{94}$ GRECO, Luís. Cumplicidade através de ações neutras. A imputação objetiva na participação. Rio de Janeiro: Renovar, 2004, p.39: "Minha principal crítica é a falta de clareza de Jakobs a respeito do caráter de sua teoria: está ele falando de uma função em sentido descritivo (o modo como o direito penal realmente opera) ou em sentido normativo/prescritivo (aquilo que o direito penal deve almejar)?". ${ }^{95}$ APONTE, Alejandro. Derecho Penal del Enemigo VS. Derecho Penal del Ciudadano. CANCIO MELIÁ, Manuel; GÓMEZ-JARA DÍEZ, Carlos (Coords.). Derecho Penal del Enemigo: El discurso penal de la exclusión. Vol.1. Madrid/Buenos Aires: Edisofer y IBdeF, 2006, vol. 1, p.176: “[...] Jakobs es, como se ha advertido, en extremo ambiguo, y esta actitud si es criticable".

${ }^{96}$ PRITTWITZ, Cornelius. O Direito Penal entre Direito Penal do Risco e Direito Penal do Inimigo: tendências atuais em direito penal e política criminal. Tradução de Helga Sabotta de Araújo e Carina Quito (Coord.). Revista Brasileira de Ciências Criminais, São Paulo, n.47, mar./abr.2004, p.44: "E parece igualmente notável e lamentável que a crítica quase unânime e dura que o conceito de Jakobs no direito penal do inimigo recebeu da ciência do direito penal alemã, na minha opinião, só se refira ao conceito. Tivesse ele escolhido outro nome, e teria recebido o aplauso de muitos colegas"

${ }^{97}$ FERRAJOLI, Luigi. El "Derecho Penal del Enemigo" y la disolución del Derecho Penal. CARBONELL, Miguel (Ed.). Democracia y garantismo. Madrid: Editorial Trotta, 2008, p.236.

${ }^{98}$ GRECO, Luís. Sobre o chamado Direito Penal do Inimigo. Revista da Faculdade de Direito de Campos, Rio de Janeiro, Ano VI, n. ${ }^{\circ}$ 7, dez.2005, p.235: 'Afinal, a palavra 'inimigo' é tão carregada valorativamente, que parece muito difícil empregá-la apenas para descrever. A mera utilização da palavra já parece criar automaticamente divisões e polarizações, que ameaçam envolver até mesmo aquele que supostamente descreve em sua irresistível dinâmica".

${ }^{99}$ FERRAJOLI, Luigi. Direito e Razão: teoria do garantismo penal. Tradução de Ana Paula Zomer, Fauzi Hassan Choukr, Juarez Tavares et al. São Paulo: RT, 2002, p.176: “[...] trata-se de uma tese meta-lógica 
GRECO sobre o catedrático de Bonn "[...] deduz de suas premissas supostamente descritivas conclusões de caráter normativo, o que já por motivos lógicos (palavrachave: falácia naturalista) só é possível se também as premissas forem normaticas" ${ }^{100}$.

\section{O 11 DE SETEMBRO...WAR AGAINST TERROR...USA PATRIOT ACT...}

Feitas as críticas de fundamento Garantista ao Feindstrafrecht, agora serão apontadas as drásticas mudanças trazidas pelos atentados de 11 de setembro de 2001 ao tratamento dispensado aos direitos fundamentais e a necessidade de enrijecimento da legislação penal e processual penal nos Estados Unidos da América. Isto leva, infelizmente, a adoção de um verdadeiro Direito Penal do Inimigo para a luta/combate contra o terrorismo, levando Cornelius PRITTWITZ a salientar que "El 11 de septiembre ha venido a confirmar lo difícil que resulta hoy dia establecer la diferencia entre el Derecho penal y guerra"101.

A principal materialização disso está no denominado USA Patriot Act (promulgado pelo Senado norte-americano em 26 de outubro de 2001). Esta norma norte americana permite a execução de prisões em decorrência do fato de pertencer ou ter conexão com pessoas de certas etnias, ignora direitos civis básicos como o direito a habeas corpus e chega ao absurdo de "[...] to compel libraries to report the books people had borrowed" 102 . Observa ainda MUNOZ CONDE que alguns dispositivos dessa mesma "carta de restrições fundamentais" norte-americana "[...]permiten al FBI, sin control judicial, detener a ciudadanos, o recabar de las empresas datos sobre la intimidad de sus clientes y trabajadores y outras muchas violaciones de derechos fundamentales[...]"103.

Outro ponto polêmico é a indeterminação legal em que alguns "inimigos" se encontram, não sendo nem acusados nem prisioneiros, mas apenas detidos, chegando-se ao absurdo de "[...] anular radicalmente todo estatuto jurídico do indivíduo, produzindo, dessa forma, um ser juridicamente inominável e inclassificável" ${ }^{104}$. Portanto, tal abordagem, trazida à baila desde 1985 pelo penalista alemão, ganha vida na atualidade, tendo em vista que o terrorismo é um dos solos férteis do tão contestado (e constatado!) Direito Penal do Inimigo, assim as legislações de inúmeros Estados têm adotado uma postura na qual são flexibilizados (quando

- precisamente uma aplicação da denominada Lei de Hume - que preclui como 'falácia naturalista' a derivação do direito válido ou 'como é' do direito justo ou 'como dever ser' e ice-versa".

${ }^{100}$ GRECO, Luís. Sobre o chamado Direito Penal do Inimigo. Revista da Faculdade de Direito de Campos, Rio de Janeiro, Ano VI, n. ${ }^{0}$ 7, dez.2005, p.227.

${ }^{101}$ PRITTWITZ, Cornelius. Derecho Penal del enemigo: ¿ Anális crítico o programa del Derecho Penal? La Política Criminal en Europa. MARTín, Víctor Gómez (Coord.), p.98.

${ }^{102}$ DWORKIN, Ronald M. Is democracy possible here? : principles for a new political debate. New Jersey: Princeton University Press, 2006, p.25.

${ }^{103}$ MUÑOZ CONDE, Francisco. De nuevo sobre el "Derecho penal del enemigo". Buenos Aires: Hammurabi, 2005, p.41.

${ }^{104}$ AGAMBEN, Giorgio. Estado de exceção. Tradução de Iraci D. Poleti. $2^{\mathrm{a} e d . ~ S a ̃ o ~ P a u l o: ~ B o i t e m p o, ~}$ 2007, p.14. 
não tolhidos) inúmeros direitos fundamentais dos cidadãos, visando à efetiva proteção dos mesmos e das estruturas do próprio Estado de Direito, como os Estados Unidos da América.

Assim, após o 11 de setembro, o inimigo está ontologicamente indicado, principalmente nas prisões de Guantánamo e de Abu Ghraib. Ora, próximo de um utilitarismo, torturas e maus-tratos foram implementados nessas prisões com a justificação de encontrar e desmantelar ações e redes terroristas. Isto fez com que MÜSSIG reconhecessse por meio de uma premonição fatídica que o direito penal do inimigo: "Como concepto afirmativo, en cambio, identifica un mundo de sombras del Derecho: el estado de excepcíon como orden. Este mundo de sombras es ya realidad y presagio fatídico: Guantánamo" ${ }^{105}$. Por fim, Fábio D'ÁVILA sustenta a contundente crítica de que:

[...] ao buscar (re)estabelecer um já conhecido modelo de direito penal do agente, direcionado à punição de atos meramente preparatórios, no qual o objetivo da pena é tão só inocuizar uma 'inaceitável' fonte de perigo, e no qual o processo se assume como instrumento de facilitação na obtenção de fins político-criminais acentuadamente demagógicos, como é o caso, v.g., da denominada 'guerra contra o terrorismo', deveria, de imediato, ser jogada no espaço crítico da indiferença e do absurdo, no espaço das idéias surreais às quais não é concedida qualquer pretensão de concretude ${ }^{106}$.

\section{6. À GUISA DE CONCLUSÃO}

O Direito Penal não é capaz de solucionar os problemas desta sociedade complexa, principalmente os do terrorismo e da criminalidade organizada, sob pena de instituirmos uma verdadeira guerra, na qual se apontam os inimigos, buscandose a todo custo sua destruição. Torna-se, de fato, e, no mínimo, perigoso, trabalhar com esta categoria no Direito Penal, pois em sua concretização alguns inocentes podem pagar o preço das "boas intenções" de segurança objetivadas por tal construção, contradizendo uma necessária postura garantista.

Além disso, em respeito à sangrenta história de opressão (cujas vítimas mais representativas foram os escravos, os doentes mentais, as bruxas, os judeus, os pobres, e hoje são os estrangeiros, os latino americanos, os africanos, os muçulmanos ${ }^{107}$ ) da humanidade, umas das cautelas deveria partir dos próprios

${ }^{105}$ MÜSSIG, Bernd. Derecho Penal del enemigo: concepto y fatídico presagio. Algunas tesis. Derecho Penal del enemigo: el discurso penal de la exclusión.v2.Buenos Aires: Editorial IbdeF, 2006, p.390.

${ }^{106}$ D'ÁVILA, Fábio Roberto. O inimigo no Direito Penal contemporâneo. Algumas reflexões sobre o contributo crítico de um Direito Penal de base onto-antropológica. GAUER, Ruth Maria Chittó (Coor.). Sistema Penal e Violência. Rio de Janeiro: Lumen Juris, 2006, p.97.

${ }^{107}$ Neste sentido é rico o estudo feito por ZAFFARONI no tocante ao inimigo na história do direito penal. Vide capítulo II - "O inimigo na prática do exercício real do poder punitivo", p.29 a 82, in ZAFFARONI, Eugenio Raúl. O inimigo no Direito Penal. $2^{\mathrm{a} e d . ~ T r a d u c ̧ a ̃ o ~ d e ~ S e ́ r g i o ~ L a m a r a ̃ o . ~ R i o ~ d e ~}$ Janeiro: Revan, 2007. 
conceitos empregados na formulação de teorias penais. Infelizmente isto acabou em segundo plano com o silêncio e o jogo sombrio de descrever e legitimar de Günther JAKOBS.

Conclui-se que o Direito Penal do Inimigo constitui uma real ameaça tanto para o futuro do Estado de Direito (substancial) quanto para o Direito Penal democrático e garantista. Por todo o exposto, e sob o risco de sua assimilação ou desvirtuamento pelos Estados, o Feindstrafrecht como teoria deve ser rechaçado pela cultura jurídica através de sua função crítica; e as normas alimentadas por (ou com ranços de) este conteúdo devem ser declaradas inválidas no sentido apontado por Luigi FERRAJOLI.

\section{REFERÊNCIAS:}

AGAMBEN, Giorgio. Estado de exceção. Tradução de Iraci D. Poleti. $2^{\mathrm{a} e d . ~ S a ̃ o ~ P a u l o: ~}$ Boitempo, 2007.

AMARAL, Cláudio do Prado. Bases Teóricas da Ciência Penal Contemporânea: dogmática, missão do direito penal e política criminal na sociedade de risco. São Paulo: IBCCRIM, 2007.

APONTE, Alejandro. Derecho Penal del Enemigo VS. Derecho Penal del Ciudadano. CANCIO MELIÁ, Manuel; GÓMEZ-JARA DÍEZ, Carlos (Coords.). Derecho Penal del Enemigo: El discurso penal de la exclusión. Vol.1. Madrid/Buenos Aires: Edisofer y IBdeF, 2006, vol. 1, p. 163-204.

CANOTILHO, José Joaquim Gomes. Justiça Constitucional e Justiça Penal. Revista Brasileira de Ciências Criminais, São Paulo, n.58, p.329-344, jan./fev.2006.

D'ÁVILA, Fábio Roberto. O inimigo no Direito Penal contemporâneo. Algumas reflexões sobre o contributo crítico de um Direito Penal de base onto-antropológica. GAUER, Ruth Maria Chittó (Coor.). Sistema Penal e Violência. Rio de Janeiro: Lumen Juris, 2006, p.95-108.

DWORKIN, Ronald M. Is democracy possible here? : principles for a new political debate. New Jersey: Princeton University Press, 2006.

FERRAJOLI, Luigi. Direito e Razão: teoria do garantismo penal. Tradução de Ana Paula Zomer, Fauzi Hassan Choukr, Juarez Tavares et al. São Paulo: RT, 2002.

Passado y futuro del Estado de Derecho. CARBONELL, Miguel (Org.) Neoconstitucionalismo(s). Madrid: Trotta, 2003, pp.13-29.

El "Derecho Penal del Enemigo" y la disolución del Derecho Penal.

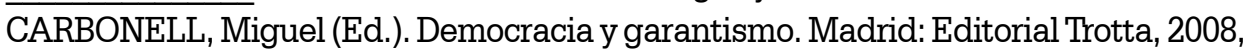
pp.234-250.

.Garantias y Derecho Penal. CARBONELL, Miguel (Ed.). Democracia y garantismo. Madrid: Editorial Trotta, 2008, pp.192-207. 
.Jurisdicción y Democracia. CARBONELL, Miguel (Ed.). Democracia

y garantismo. Madrid: Editorial Trotta, 2008, pp.208-219.

La legalidad violenta. CARBONELL, Miguel (Ed.). Democracia y garantismo. Madrid: Editorial Trotta, 2008, pp.175-191.

GRECO, Luís. Cumplicidade através de ações neutras. A imputação objetiva na participação. Rio de Janeiro: Renovar, 2004.

. Sobre o chamado Direito Penal do Inimigo. Revista da Faculdade de Direito de Campos, Rio de Janeiro, Ano VI, n. ${ }^{\circ}$ 7, p.211-247, dez.2005.

HEGEL, Georg Wilhem Friedrich. Princípios da Filosofia do Direito. Tradução de Orlando Vitorino. São Paulo: Martins Fontes, 1997.

JAKOBS, Günther. Criminalización em el estadio previo a la lesión de un bien juridico. Estudios de Derecho Penal. Traducción de Enrique Peñaranda Ramos, Carlos J. Suárez González y Manuel Cancio Meliá. Madrid: Civitas, 1997.

Personalidad y exclusión en derecho penal. In: MONTEALEGRE LYNETT, Eduardo (Coord.). El Funcionalismo en Derecho Penal. Libro Homenaje al professor Günther Jakobs. Bogotá: Universidad Externado de Colombia, 2003, p.7190.

Ciência do Direito e Ciência do Direito Penal. Tradução de Maurício Antonio Ribeiro Lopes. Barueri: Manole, 2003.

Derecho Penal del Ciudadano y Derecho Penal del Enemigo. In: JAKOBS, Günther; CANCIO MELIÁ, Manuel. Derecho Penal del Enemigo. Madrid: Civitas, p.19-56, 2003.

;Derecho Penal del Ciudadano y Derecho Penal del Enemigo. In:__ ; POLAINO NAVARRETE, Miguel. El Derecho Penal ante las sociedades modernas: dos estúdios de dogmática penal y política criminal. Lima: Grijley, 2006, p.21-46.

. Derecho penal del enemigo? Un estudio acerca de los presupuestos de la juridicidad. Traddución de Manuel Cancio Meliá. Panóptica, Vitória, ano 2, n. 11, p.197-213, nov. - fev. 2008.

KELSEN, Hans. Teoria Pura do Direito. 4aed. Tradução de João Baptista Machado. Coimbra: Armênio Amado Editor, 1976.

LOMBROSO, Cesare. O homem criminoso. Tradução de Maria Carlota Carvalho Gomes. Rio de Janeiro: Editora Rio, 1983.

LUHMANN, Niklas. Sociologia do Direito. v.1 Tradução de Gustavo Bayer. Rio de Janeiro: Tempo Brasileiro, 1983. 
Sociologia do Direito II. Tradução de Gustavo Bayer. Rio de Janeiro: Edições Tempo Brasileiro, 1985.

A restituição do décimo segundo camelo: do sentido de uma análise sociológica do Direito. In: ARNAUD, A; LOPES JR., D (Coord.). Niklas Luhmann: do sistema social à sociologia jurídica. Rio de Janeiro: Lumen Juris, 2004, pp.33-107.

. El Derecho como sistema social. In: GÓMEZ-JARA DÍEZ, Carlos (ed.). Teoría de sistemas y Derecho penal. Fundamentos y posibilidades de aplicación. Granada: Editorial Comares, 2005, pp.69-85.

. Are There Still Indispensable Norms in Our Society? Translated by Todd Cesaratto. Soziale Systeme 14 (2008), Heft 1, S. 18-37. Disponível em: < http://www.soziale-systeme.ch/pdf/sozsys_1-2008_luhmann-norms.pdf $>$. Acesso em: 10.set.2009.

MUÑOZ CONDE, Francisco. El nuevo Derecho penal autoritário. In: LOSANO, Mario G.; MUÑOZ CONDE, Francisco (Coord.). El Derecho ante la globalización y el terrorismo. Valencia: Tirant lo blanch, p. 161-183, 2004.

Aires: Hammurabi, 2005.

.De nuevo sobre el "Derecho penal del enemigo". Buenos

. Edmund Mezger e o Direito Penal de seu tempo. $4^{\mathrm{a} e d .}$

Tradução de Paulo César Busato. Rio de Janeiro: Lumen Juris, 2005.

MÜSSIG, Bernd. Derecho Penal del enemigo: concepto y fatídico presagio. Algunas tesis. Derecho Penal del enemigo: el discurso penal de la exclusión.v2.Buenos Aires: Editorial IbdeF, 2006, p.371-390.

POLAINO ORTS, Miguel. Derecho penal del enemigo: desmitificación de un concepto. Lima: Grijley, 2006.

PRITTWITZ, Cornelius . O Direito Penal entre Direito Penal do Risco e Direito Penal do Inimigo: tendências atuais em direito penal e política criminal. Tradução de Helga Sabotta de Araújo e Carina Quito (Coord.). Revista Brasileira de Ciências Criminais, São Paulo, n.47, p.31-45, mar./abr.2004.

Derecho Penal del enemigo: ¿ Anális crítico o programa del Derecho Penal? In: MIR PUIG, Santiago, CORCOY BIDASOLO, Mirentxu (Dir.). La política criminal en Europa. Barcelona: Atelier, 2004, p.107-119.

SILVA SÁNCHEZ, Jesús-Maria. A expansão do direito penal: aspectos da política criminal nas sociedades pós-industriais. Tradução de Luiz Otavio de Oliveira Rocha. São Paulo: RT, 2002.

ZAFFARONI, Eugenio Raúl. O inimigo no Direito Penal. $2^{\mathrm{a}}$ ed. Tradução de Sérgio Lamarão. Rio de Janeiro: Revan, 2007. 